Aneta Wielgosz

Uniwersytet Warszawski

\title{
Autocenzura w pierwszych polskich przekładach Gianniego Rodariego
}

Jak zauważa izraelska specjalistka od przekładu literatury dziecięcej, Zohar Shavit, w swoich inspirowanych teorią polisystemu literackiego (autorstwa Itamara Ewena-Zohara) badaniach, tłumaczona literatura dziecięca znajduje się na marginesach tegoż polisystemu, a zatem jej tłumacze mogą pozwolić sobie na bardziej swobodne manipulacje tekstem niż tłumacze literatury, której odbiorcami są dorośli. Tłumacze literatury dziecięcej mogą właściwie dowolnie manipulować tekstem źródłowym i uniknąć krytyki, jeżeli tylko przestrzegają dwóch podstawowych zasad:

a. Modyfikują tekst tak, aby uczynić go odpowiednim i użytecznym dla dziecka, w zgodzie z tym, co według społeczeństwa jest dobre dla dziecka.

b. Dostosowują fabułę, charakterystykę postaci oraz język do zdolności pojmowania dziecka oraz do poziomu jego umiejętności czytania ${ }^{1}$ (Shavit 171-172).

1 “The translator of children's literature can permit himself great liberties regarding the text because of the peripheral position children's literature occupies in the polysystem. He is allowed to manipulate the text in various ways, as long as he considers the following principles on which translation for children is usually based: 
Przekładający literaturę dla dzieci często zatem dokonują manipulacji na tekście źródłowym ze względu na fakt, że społeczeństwo uważa książki za ważny element $\mathrm{w}$ wychowywaniu młodych pokoleń, a pewne zawarte $\mathrm{w}$ nich treści - za szkodliwe lub nieodpowiednie dla odbiorcy w danym wieku. Shavit uważała, że dzieje się tak przede wszystkim ze względu na nikłe znaczenie literatury dziecięcej w polisystemie literackim: podobną pozycję zajmuje literatura dla dorosłych spoza głównego nurtu, na przykład literatura gatunkowa (Shavit 171-172). Jak zauważa niemiecka badaczka Gabi Thomson-Wohlgemuth, inaczej jest w przypadku państw o systemie totalitarnym i autorytarnym, w których ważną częścią wychowania jest indoktrynacja ideologiczna. To właśnie dzięki kluczowej roli literatury dziecięcej w polisystemie jej tłumaczenia często podlega ona różnorakim manipulacjom i cenzurze nie tylko ze strony aparatu państwowego, lecz także samych tłumaczy. Thomson-Wohlgemuth pisze o tym w swojej książce Translation under State Control. Books for Young People in German Democratic Republic:

Ponieważ książki miały za zadanie raczej wychowywanie ludności niż dostarczanie rozrywki, książki dla dzieci miały wychowywać młodsze pokolenia. Powaga tego zamiaru wywarła niezwykle wielki wpływ na problemy literackie. Ponieważ literatura dziecięca miała taką samą, jeśli nie większą, wagę jako narzędzie dydaktyczne, była traktowana z taką samą powagą jak literatura dla dorosłych. Jednakże bez wątpienia nie tylko jej funkcja jako narzędzia wychowawczego zrównała literaturę dziecięcą z literaturą dla dorosłych. Według jednego z podstawowych założeń marksizmu-leninizmu, dzieci są zaangażowane w konstruowanie i utrzymywanie społeczeństwa tak samo jak starsze pokolenia. Są widziane jako partnerzy dorosłych w rozwoju społecznym, sprzymierzeńcy w konflikcie klasowym, aktywni budowniczy socjalizmu i potencjalni przedstawiciele przyszłości. Dodatkowo, społeczeństwo socjalistyczne to społeczeństwo bezklasowe, $\mathrm{w}$ związku z tym istnieje w nim tylko jedna kultura (w przeciwieństwie do burżuazyjnego systemu kultur i podkultur), a więc dziecko i dorosły mogą być jednością - co stoi w przeciwieństwie do burżuazyjnego konfliktu pokoleniowego. W kon-

a. Adjusting the text in order to accordance with what society thinks

b. Adjusting plot, characterization and language to the child's level of comprehension and his reading abilities".

Tłumaczenie tekstów obcojęzycznych w artykle pochodzi od Autorki - A.W. 
sekwencji, w socjalizmie dzieci są widziane jako równie wartościowe jak dorośli i posiadające równe prawa² (Thomson-Wohlgemuth 3).

Niemiecka badaczka w cytowanej wyżej książce wyróżnia kilka kategorii, pod względem których publikacje przeznaczone dla dzieci i młodzieży najczęściej były cenzurowane i oceniane, zarówno prewencyjnie przez tłumaczy, jak i przez przedstawicieli aparatu państwowego recenzujących przekłady i dopuszczających je do publikacji. Były to: pozytywne opinie na temat kapitalizmu i imperializmu, burżuazyjnych wartości, elementy dotyczące systemu klasowego, faszyzm, religia i przesądy, przemoc, przestępstwa i seks, chuliganizm, narkotyki, elementy fantastyczne, rasizm i kolonializm, sentymentalizm i romantyzm, myślenie apolityczne, obojętność i bierność, indywidualizm, elementy formalistyczne i podejście na zasadzie „sztuki dla sztuki”. Z kolei elementami pozytywnymi i poszukiwanymi w literaturze dla najmłodszych były: współczesność i odniesienia do codziennego życia, etos pracy i nauki, solidarność z innymi, zaangażowanie i inicjatywa, lojalność wobec socjalizmu, pacyfizm, bohaterowie pozytywni, którzy mogą być wzorem do naśladowania, użyteczność wychowawcza, krytyka społeczna (Thomson-Wohlgemuth 115-116). Wiele $\mathrm{z}$ tych elementów można odnaleźć w dwóch powieściach Rodariego: Opowieść o Cebulku (Il romanzo di Cipollino, a w późniejszych wydaniach Le avventure di Cipollino) z 1951 roku i Gelsomino w Kraju Kłamczuchów (Gelsomino nel paese dei bugiardi) z 1959 roku: ich bohaterowie solidaryzują się z innymi, zawsze stają w obronie wykluczonych, podejmują inicjatywę mimo trudnych sytuacji. Zawierają one także wiele elementów krytyki społecznej, Rodari portretuje dzieci

2 "As books were given the mission to educate the general populace rather than purely entertain, children's books had to educate the younger generation. It was the seriousness of this intention that put immense pressure on literary matters. As it had the same, if not greater, importance as a didactic tool as adult literature, children's literature was placed on a par with general literature. However, it was without a doubt not only their function as an educational tool, similar to adults' books, which helped embed children's books in mainstream literature. According to one of the basic principles of Marxism-Leninism, children are involved in constructing and maintaining society as much as the older generation. They are viewed as "partners of the adults in societal development, as allies in the class struggle, as active builders of socialism and as potential representatives of the future". Additionally, a socialist society is a classless one, from which it follows that there is only one single culture (as opposed to the bourgeois system of cultures and subcultures), thus a notion that leads to child and adult forming a unit (as opposed to the bourgeois generation conflict). Consequently, children are regarded by socialism as of equal value and deserving of equal rights to adults". 
należące do proletariatu w opozycji do ich burżuazyjnych wrogów. Z drugiej strony, obaj główni bohaterowie, Cebulek i Gelsomino, są silnymi indywidualnościami, a w ich historiach obecne są przemoc, cierpienie i śmierć.

Manipulacje tekstem w tłumaczeniach literatury dziecięcej są szczególnie powszechne w krajach i w czasach, w których jest ona widziana przede wszystkim jako narzędzie wychowawcze, a nie jako forma rozrywki, co więcej, jako narzędzie służące do wpajania ideologii państwowej. Takim państwem była też Polska Rzeczpospolita Ludowa. Teksty literatury dziecięcej, zwłaszcza te pochodzące z krajów spoza bloku wschodniego, były dobierane szczególnie starannie. Jak wynika z badań przeprowadzonych przez Katarzynę Biernacką-Licznar, spośród pisarzy włoskich, poza klasykami takimi jak Carlo Collodi i Edmondo De Amicis, często tłumaczone były książki Gianniego Rodariego i Marcella Argillego (Biernacka-Licznar 92). W przeznaczonych dla dzieci utworach tych autorów, należących do Włoskiej Partii Komunistycznej, często pojawiają się elementy antymonarchistyczne, pacyfistyczne i socjalistyczne. Również z tego powodu ich dzieła zdobyły popularność w Związku Radzieckim zanim jeszcze stały się słynne we Włoszech. Mówi o tym Roberto Cicala w analizie listów Rodariego do redakcji, zauważa także, że książki autora zaczęły ukazywać się w prestiżowym wydawnictwie Einaudi dopiero w latach sześćdziesiątych, a więc gdy już wszystkie z nich były przetłumaczone na rosyjski (Cicala 21-22). Po sukcesie w ZSRR pojawiło się wiele przekładów w innych krajach bloku wschodniego, między innymi w NRD (pierwsze tłumaczenie w 1964 roku), na Węgrzech (pierwszy przekład Opowieści o Cebulku ukazał się w 1956 roku i był olbrzymim sukcesem wydawniczym) czy w Czechosłowacji. W Polsce pierwsze tłumaczenia wierszy Gianniego Rodariego pojawiły się na początku lat pięćdziesiątych na łamach czasopism przeznaczonych dla dzieci, jego powieść Opowieść o Cebulku została przełożona przez Zofię Ernstową w 1954 roku, czyli trzy lata po oryginalnym włoskim wydaniu. Kolejnym sukcesem wydawniczym była książka Gelsomino w Kraju Kłamczuchów, przełożona przez Hannę Ożogowską w 1962 roku, a więc trzy lata po ukazaniu się jej we Włoszech. Obie tłumaczki to znane postaci polskiego świata literackiego - Zofia Ernstowa tłumaczyła najsłynniejszych autorów i autorki z Włoch, a Hanna Ożogowska to wybitna pisarka tworząca dla dzieci i młodzieży. W artykule chciałabym zaprezentować manipulacje tekstem, które można odnaleźć w tych przekładach. Niektóre z nich dotyczą kwestii ideologicznych, inne są związane z omijaniem tematów uważanych za tabu w literaturze dziecięcej, takich jak śmierć czy wojna. Warto dodać, że według badań przeprowadzonych przez Katarzynę Biernacką-Licznar, cenzorzy nie mieli żadnych zastrzeżeń co do publikacji tych książek (Biernacka-Licznar 63). 
Powieść Gelsomino w Kraju Kłamczuchów opowiada o chłopcu imieniem Gelsomino, który jest obdarzony niezmiernie silnym i niemożliwym do opanowania głosem. Pewnego dnia tytułowy bohater wybiera się w podróż i trafia do krainy, w której, zgodnie z obwiązującym prawem ustanowionym przez złego króla, byłego pirata, wszyscy kłamią - nawet koty nie miauczą, a szczekają. Natomiast Opowieść o Cebulku to historia o warzywach i owocach żyjących w krainie władanej przez złego Księcia Pomarańczę. Przywódcą rebelii przeciw niemu staje się młody Cebulek, który decyduje się zbuntować, gdy książę wtrąca do więzienia jego ojca.

Najpierw przeanalizowane zostaną fragmenty, w których zmodyfikowane są elementy mówiące o różnicach klasowych.

Pierwszy rozdział Gelsomina w Kraju Kłamczuchów opowiada o przygodach tytułowej postaci w szkole. Później autor wprowadza czytelnika w dalsze losy bohatera:

[...] non era più uno scolaro, da un pezzo, ma un contadino, e tale sarebbe rimasto, e non ci sarebbe nessuna storia speciale da raccontare su di lui, se non gli fosse capitata la spiacevole avventura, che adesso conoscerete (Rodari 2010: 14).

[...] od jakiegoś czasu nie był już uczniem, lecz chłopem, i pozostałby nim, i nie byłoby żadnej szczególnej historii do opowiedzenia o nim, gdyby nie zdarzyła się mu pewna nieprzyjemna przygoda, którą teraz poznacie (przeł. A.W.).

Ten fragment zostaje zupełnie pominięty w wersji Hanny Ożogowskiej, prawdopodobnie ze względu na fakt, że mówi o niemożliwości awansu społecznego.

Rodari w Opowieści o Cebulku tak opisuje znajdujący się przy zamku należącym do krewnych władcy warzyw i owoców park:

Una parte era destinata ai ragazzi del villaggio, perché non gli venisse la tentazione di scavalcare l'inferriata per andare a giocare sotto gli alberi del palco: l'altra era per Cilegino, perché non gli venisse la tentazione di scappare nel villaggo a imbrancarsi con i figli dei poveri (Rodari 2009: 48).

Jedna część była przeznaczona dla dzieci z wioski, aby nie przyszła im pokusa przejścia przez żelazne ogrodzenie, by pójść się pobawić pod drzewa parku: druga była dla Wisienka [siostrzeńca władcy], aby 
nie przyszła mu pokusa ucieczki do wioski i wmieszania się w dzieci biedaków.

U Ernstowej ten fragment jest oddany następująco: „Jedna strona przeznaczona była dla dzieci wiejskich, żeby nie kusiło ich przełazić przez bramę i bawić się pod drzewami parku, a druga strona dla Wisienka, żeby nie kusiło go wymknąć się na spacer do wioski” (Rodari 1954: 18). Warto zwrócić uwagę, jak mocno brzmi tutaj włoski czasownik „imbrancarsi”, który pochodzi od słowa „branco”, ‘stado’ i dosłownie mógłby znaczyć „wmieszać się w obce stado”. Wisienek jest jednym z nielicznych jednoznacznie pozytywnych bohaterów należących do burżuazji w książkach Rodariego i zdaje się, że tłumaczka usiłowała wymazać kwestię różnicy klasowej między nim a Cebulkiem i innymi pochodzącymi $\mathrm{z}$ proletariatu bohaterami.

W kilku miejscach tłumaczki, zwłaszcza Ernstowa, pomijają wyrażenia związane ze sferą religijną, które są bardzo powszechne w potocznym języku włoskim. Na przykład kiedy jednej z bohaterów zostaje skazany na śmierć (egzekucja zostaje udaremniona przez Cebulka i przyjaciół), myśli: „Stavolta sono morto davvero. Sento già le voci del Paradiso” (Rodari 2009: 100), czyli „Tym razem naprawdę umarłem. Słyszę już głosy z raju”, w polskim tłumaczeniu to drugie zdanie zostaje pominięte, bohater mówi tylko „tym razem umarłem na dobre” (Rodari 1954: 100). Kiedy z kolei dwóch bohaterów odkrywa piwnicę pełną najlepszych win, jeden z nich uznaje je za dar od Boga - „Ferma! Ferma! gridava il Barone. - Guardate quanta grazia di Dio” (Rodari 2009: 146) - „Stój! Stój! - krzyczał baron. - Popatrzcie, ile łaski Bożej!”, a u Ernstowej „Stój, Stój! krzyczał Baron - Popatrz, co tu za wspaniałości” (Rodari 1954: 61). Kilka stron później ten sam bohater zaprasza: „Perché non aproffittate anche voi di tutto questo ben di Dio” (Rodari 2009: 147) - „Dlaczego i wy nie skorzystacie z tego całego dobra Bożego”, a w wersji Ernstowej „Dlaczego nie korzystasz z tych wspaniałości” (Rodari 1954: 62).

Obie tłumaczki, a szczególnie Ożogowska, pomijają lub łagodzą fragmenty związane ze śmiercią lub przemocą. Kiedy Gelsomino decyduje się wyruszyć w drogę, podaje przyczyny swojej decyzji, wśród których jest także następująca: "I miei genitori sono morti, i miei migliori amici sono caduti in guerra” (Rodari 2010: 18) - dosłownie „Moi rodzice nie żyją, moi najlepsi przyjaciele zginęli na wojnie”, a u Ożogowskiej: „Rodzice moi nie żyją, najbliżsi ich przyjaciele zginęli na wojnie" (Rodari 2017: 17). Tym sposobem tłumaczka pomija wspomnienie trudnego tematu, jakim jest śmierć przyjaciół, jak wynika z fabuły - młodych osób. Luigi Rossi, który badał przekłady omawianej powieści na język niemiecki (powstało ich kilka, zarówno w NRD, jak i w RFN), zauważył, że podobny zabieg 
został zastosowany właśnie w jednym z niemieckich tłumaczeń: jego zdaniem, pominięcie tematu niedawno zakończonej wojny osłabia pacyfistyczną wymowę tej powieści (Rossi 136-137).

W kraju kłamczuchów król nosi zawsze pomarańczową perukę, aby zakryć łysinę. Jednak kiedy Gelsomino występuje w królewskim teatrze, swoim potężnym głosem zdmuchuje mu ją z głowy. Nikt z dworzan nie ośmiela się powiedzieć prawdy władcy kłamców, zatem kiedy odkrywa on, co się stało, decyduje: „Quella sera, si dice, fece tagliare la lingua a tutti i cortigiani che stavano con lui a teatro, perché non l'avevano avvertito del disastroso incidente” (Rodari 2010: 72) - „Tego wieczoru, jak się mówi, kazał uciąć języki wszystkim dworzanom, który byli z nim w teatrze, ponieważ nie powiadomili go o katastrofalnym wypadku", a w wersji Hanny Ożogowskiej: „Tego wieczora - powiedział sobie - każę uciąć języki wszystkim dworzanom, którzy byli ze mną w teatrze i nie powiedzieli mi o tym nieszczęśliwym wypadku” (Rodari 2017: 66). W polskiej wersji zatem, poprzez zamianę czasu przeszłego na czas przyszły i dodanie słów „powiedział sobie”, ten akt przemocy zostaje przedstawiony jako jedynie pomyślany, a nie dokonany.

W opowieść o Gelsominie wpleciona jest historia Benvenuta, dobrego gałganiarza. Przechodząc koło wiejskiej lepianki, widzi on kobietę, która jest chora i nie może zajmować się swoimi licznymi dziećmi, decyduje się zatem z nimi pobawić. Dziękując mu, kobieta mówi: „[...] ero così disperata che avevo deciso di ammazzarmi” (Rodari 2010: 105) - „byłam tak zdesperowana, że zdecydowałam się zabić”, a w wersji Ożogowskiej „Byłam już tak zrozpaczona, że życie stało mi się niemiłe" (Rodari 2017: 94). W oryginale widzimy wyraźnie, że bohaterka miała zamiar popełnić samobójstwo, zaś w polskiej wersji nie wspomina się o tym, a cała jej wypowiedź zostaje znacznie złagodzona. Warto także podkreślić, że Rodari podkreśla wymowę słów bohaterki, używając bardzo potocznego czasownika: „ammazzarsi” oznacza 'zabić się’ („ammazzare qualcuno”: 'zabić, zamordować kogoś, neutralnym czasownikiem byłoby „suicidarsi”: 'popełnić samobójstwo'). To przykład alteracji, która niekoniecznie jest związana z ideologią państwową i z kwestiami politycznymi w ogóle: nawet dziś trudno wyobrazić sobie tak wyraźne nawiązanie do problemu samobójstwa w książce przeznaczonej dla dzieci w wieku, według przytaczanej przez Biernacką-Licznar recenzji cenzorskiej, od 7 do 10 lat (Biernacka-Licznar 64).

Kolejna manipulacja odnaleziona w tym przekładzie jest dosyć subtelna, ale znacząca. W oryginalnym tekście Rodariego bohater postanawia przekroczyć granicę swojego kraju i udać się do innego - „Gelsomino, qualche giorno dopo, varcava il confine e scendeva nel paese più strano di questo mondo" (Rodari 2010: 19) - „Gelsomino kilka dni później przekraczał granicę i wkraczał do najdziwniejszego kraju tego świata”. Włoski czasownik „varcare” kojarzy się 
z przekraczaniem jakiejś przeszkody, właśnie tak jak w wyrażeniu „varcare il confine” („przekroczyć granicę”, często nielegalnie, „varcare Rubicon” - przekraczać Rubikon, „varcare la soglia” - przekraczać próg). Natomiast w wersji Ożogowskiej Gelsomino po prostu „znalazł się” za granicą, jakby wbrew własnej woli: „Wkrótce za granicą znalazł się i Gelsomino” (Rodari 2017: 18). Tłumaczka cenzuruje tu element wskazujący na indywidualizm bohatera, ale też kojarzący się z łamaniem prawa: mógłby on wręcz zostać odebrany jako pochwała i zachęta do podobnych czynów.

Ernstowa cenzuruje natomiast pewien fragment, który w dzisiejszych czasach z pewnością brzmi rasistowsko. Jedna z ciotek Wisienka, Donna Prima, brudzi się podczas ucieczki i spotyka swojego kuzyna, który jej nie poznaje. Wywiązuje się pomiędzy nimi następujący dialog:

- Carissimo, carissimo! - gridò affettuosamente Donna Prima, accorrendo verso di lui impolverata e scarmigliata. - Signora, non ho lonore di conoscervi. Non sono mai stato in Africa.

- Ma sono io, Donna Prima.

- O cielo, ma che cosa vi è venuto in mente di tingervi di nero! (Rodari 2009: 159).

W dosłownym tłumaczeniu ten fragment brzmi następująco:

- Najdroższy, najdroższy! - krzyknęła z uczuciem Donna Prima, biegnąc do niego zakurzona i rozczochrana.

- Pani, nie mam przyjemności Was znać. Nie byłem nigdy w Afryce.

- Ale to ja, Donna Prima.

- O niebiosa, ale co Wam przyszło do głowy, żeby pomalować się na czarno.

Ernstowa nie wspomina o malowaniu się na czarno, osłabiając również wymowę tego żartu:

- Najdroższy kuzynie! - wołała z rozczuleniem Donna Prima biegnąc mu na spotkanie, zakurzona i potargana, tak jak podniosła się po upadku.

- O pani! Nie mam przyjemności jej znać. Nie byłem nigdy w Afryce.

- Ależ to ja, Donna Prima.

- Wielkie nieba! Co też ci przyszło do głowy, aby zrobić z siebie takie czupiradło! (Rodari 1954: 67). 
Podsumowując, widzimy, że polskie tłumaczki pierwszych powieści Rodariego świadomie dokonują manipulacji tekstowych, nawet radykalnych, takich jak pomijanie całych fragmentów tekstu. Robią to w dwojakim celu pierwszym z nich jest ochrona młodego czytelnika przed treściami dla niego nieodpowiednimi - opisami przemocy czy śmierci, które często występują w twórczości autora Opowieści o Cebulku i Gelsomina w kraju kłamczuchów. Są to zabiegi, które do dziś bywają stosowane w literaturze dziecięcej. Drugi powód jest ściśle związany z systemem, w ramach którego tworzą i który traktuje literaturę dziecięcą jako narzędzie edukacyjne i propagandowe, z czego wynika cenzura elementów takich jak indywidualność bohaterów, różnice klasowe czy też kwestie rasowe. Warto zauważyć, że o ile w przekładzie Ernstowej, w latach pięćdziesiątych, o wiele częściej cenzurowane są kwestie ideologiczne, to Ożogowska w latach sześćdziesiątych skupia się na łagodzeniu elementów związanych ze śmiercią i przemocą.

\section{| Bibliografia}

Biernacka-Licznar, Katarzyna. Serce Pinokia. Włoska literatura dla dzieci i młodzieży w Polsce w latach 1945-1989. Warszawa: Wydawnictwo Naukowe i Edukacyjne Stowarzyszenia Bibliotekarzy Polskich, 2018.

Cicala, Roberto. “Tutte le lingue della fantasia: Rodari e le traduzioni nelle lettere alla Einaudi”. Rodari: le storie tradotte. Red. P. Boero et al. Novara: Interlina, 2002. S. 21-27.

Rodari, Gianni. Gelsomino nel paese dei bugardi. Trieste: Einaudi Ragazzi, 2010.

Rodari, Gianni. Gelsomino w Kraju Kłamczuchów. Przeł. Hanna Ożogowska.

Warszawa: Polityka, 2017.

Rodari, Gianni. Le avventure di Cipollino. Trieste: Einaudi Ragazzi, 2009.

Rodari, Gianni. Opowieść o Cebulku. Przeł. Zofia Ernstowa. Warszawa: Nasza Księgarnia, 1954.

Rossi, Luigi. "Il Rodari tradito". Rodari: le storie tradotte. Red. P. Boero et al. Novara: Interlina, 2002. S. 117-151.

Shavit, Zohar. "Translation of Children's Literature as a Function of Its Position in the Literary Polysystem". Poetics Today 4 (1981). S. 171-179.

Thomson-Wohlgemuth, Gabi. Translation under State Control. Books for Young People in German Democratic Republic. New York: Routledge, 2009. 


\section{| Abstrakt}

\section{Aneta Wielgosz}

Autocenzura w pierwszych polskich przekładach Gianniego Rodariego

Jak dowodzi Gaby Thomson-Wohlgemuth w poświęconej tłumaczeniom anglojęzycznej literatury dziecięcej w NRD pracy Translation under State Control: Books for Young People in the German Democratic Republic, książki dla dzieci i młodzieży, uznawane na przykład przez izraelską badaczkę Zohar Shavit za margines polisystemu literackiego (według teorii Itamara Even-Zohara) w sytuacji, w której władza centralna próbuje kontrolować i podporządkowywać sobie obieg wydawniczy, zaczynają zajmować centralne miejsce w polisystemie jako pierwsze narzędzie służące do wychowywania posłusznych obywateli. W takim przypadku niezwykle ważny staje się też wybór obcojęzycznych książek do tłumaczenia oraz kontrola i cenzura gotowych przekładów.

W Polsce po 1945 roku najczęściej tłumaczonymi dziełami literatury dziecięcej, poza klasycznymi pozycjami, takimi jak Pinokio Carla Collodiego czy Serce Edmonda de Amicisa, były książki autorów związanych z marksizmem i z Włoską Partią Komunistyczną - Gianniego Rodariego i Marcella Argilliego. Ich powieści dla młodzieży często zawierały treści antymonarchistyczne, antykapitalistyczne czy związane z równością klasową. Cenzorzy, jak wynika z badań przeprowadzonych przez Katarzynę Biernacką-Licznar, nie mieli zastrzeżeń do treści tych przekładów. Chciałabym jednak pokazać na przykładzie tłumaczeń pierwszych dwóch powieści Gianniego Rodariego: Opowieści o Cebulku autorstwa Zofii Ernstowej z 1954 roku i Gelsomina w Krainie Kłamczuchów Hanny Ożogowskiej z 1962 roku stosowane przez tłumaczki zabiegi autocenzury, na przykład omijanie kontrowersyjnych fragmentów tekstu. Tłumaczki, mając świadomość istnienia instytucji cenzora, celowo manipulowały tekstem, aby ułatwić bezproblemowe wydanie tych powieści.

Słowa kluczowe: literatura dziecięca, Gianni Rodari, Zofia Ernstowa, cenzura, autocenzura, Hanna Ożogowska

\section{| Abstract}

Aneta Wielgosz

Self-Censorship in the First Polish Translations of Gianni Rodari

As Gaby Thomson-Wohlgemuth proves in her book Translation under State Control: Books for Young People in the German Democratic Republic, books for children and 
young people considered, for example, by the Israeli researcher Zohar Shavit to be a periphery of the literary polysystem (according to Itamar Even-Zohar's theory), in a situation where the central authority tries to control and subordinate the publishing circuit begin to occupy a central place in the polysystem as the first tool for raising obedient citizens. In this case, the selection of foreign-language books to be translated and the control and censorship of existing translations also become extremely important.

In Poland after 1945, the most frequently translated Italian children's book, apart from classics such as Carl Collodi's Pinocchio or Edmondo de Amicis' Heart, were books by authors connected with Marxism and with the Italian Communist Party - Gianni Rodari and Marcello Argilli. Their novels for young people often contained anti-monarchist and anti-capitalist content. Censors, according to research conducted by Katarzyna Biernacka-Licznar, had no objections to the content of these translations. However, I would like to show, using the example of the translations of the first two novels by Gianni Rodari: Il romanzo di Cipollino (Opowieść o Cebulku) by Zofia Ernstowa from 1954 and Gelsomino nel paese dei bugiardi (Gelsomino w kraju kłamczuchów) by Hanna Ożogowska from 1962, how the translators used self-censorship procedures, such as avoiding controversial fragments of the text. The translators, aware of the existence of the censor's institution, deliberately manipulated the text in order to facilitate the publication of these novels.

Keywords: children's literature, Gianni Rodari, Zofia Ernstowa, censorship, selfcensorship, Hanna Ożogowska

\section{| Nota o autorze}

Aneta Wielgosz - doktorantka Uniwersytetu Warszawskiego. Jej zainteresowania naukowe koncentrują się wokół włoskiej literatury dziecięcej, jej przekładów na język polski oraz europejskiego komiksu i powieści graficznej.

E-mail: aneta.agnieszka.wielgosz@gmail.com 
